\title{
MODEL STRATEGY FOR PERFORMANCE IMPROVEMENT USING BALANCE SCORECARD ON COMPANY ON COMPANY ELECTRICAL DISTRIBUTORS
}

\author{
Arasy Alimudin*1, Reswanda T Ade ${ }^{2}$ and Sri Wiwoho Mudjanarko ${ }^{3}$ \\ ${ }^{1,2}$ Departement of Management, Narotama University, Surabaya, Indonesia. \\ (E-mail: arasy.alimudin@ narotama.ac.id, reswanda@narotama.ac.id) \\ ${ }^{3}$ Civil Engineering, Narotama University, Surabaya, Indonesia. \\ (E-mail: sri.wiwoho@narotama.ac.id)
}

\begin{abstract}
The turbulent and complex business environment demands that an organization keeps updating its business travel map; take a strategic step that focuses the capabilities and commitment of all personnel to realize the organization's ideal future. Innovative companies use a balanced scorecard as a strategic management system that manages corporate strategy on a continuous basis. The Strategy Model using balanced scorecard on the company's electrical distributor is a strategic and operational business plan that is developed through the following steps: 1) description of vision and mission becomes the goal; 2) description of objectives into strategic advice; 3) Strategic description becomes a strategic initiative to achieve strategic objectives; 4) description of strategic initiatives into a program; and 5) a description into the budget program. The goal to be achieved in this research is to know the performance on the company's electrical distributor in improving profitability. The Balanced Scorecard analysis in the firm found that the financial perspective score 5, the Customer Perspective 3.08, the Internal Business Process Perspective of 3.04, and the Learning and Growth Perspective 2.7. Based on the results of the company score then determine the strategy to increase sales volume by increasing customer satisfaction through quality products with competitive prices, and increase the number of stock items. Optimizing the profit earned, so as to increase the company's ability to return capital to shareholders, by limiting the cost to the owner's personal needs.
\end{abstract}

Keywords: Strategy, balanced scorecard, electrical distributor, performance.

\section{INTRODUCTION}

The turbulent and complex business environment demands that an organization keeps updating its business travel map; take a strategic step that focuses the capabilities and commitment of all personnel to realize the organization's ideal future. Innovative companies use a balanced scorecard as a strategic management system that manages corporate strategy on a continuous basis. The Company's Trafindo is a vertically integrated Distributor company with export orientation. The Company's Trafindo is headquartered in Jakarta with operations spread across Indonesia. The 
Company's Trafindo activities are integrated from many requests of the Transformers State Company's electricity. As one of Distributor in Eastern Indonesia. The Company must maintain product quality and Consumer Satisfaction. The ability to maintain Product Quality and Customer Satisfaction is highly dependent on its performance. To have a comprehensive work assessment, it can balance the financial and non financial aspects. Therefore, the focus of the problem can be studied more deeply through this research, then the required performance measurement is Balanced Scorecard Holistically, many things happen in the business world, not to mention the company of electrical in Surabaya. Because of the complexity of the problems that exist, the more comprehensive the related elements.

\section{PROBLEM STATEMENT}

Based on the results of interviews and identification of problems that arise so far are: 1 . How is the quality and quality of goods; 2. How to Order Goods Specification; 3. What about the price offer; 4. How the Level of Customer Satisfaction (customer satisfaction); 5. How to Masterhip Market share (market share); 6. How Ability to retain old customers (customer retention).

The goal to be achieved in this research is to know the performance on the company of Distributor Electrical in improving profitability. In this case measured by Balanced Scorecard which includes four perspectives of financial perspective, customer perspective, internal business process perspective and learning and growth perspective[1].

1) Financial Perspective

Financial Perspective is a measure of performance using financial indicators, indicators that can be used as follows[2]:

1. ROI (Return On Investment)

2. ROE (Return On Equity)

3. ROA (Return on Asset)

4. Sales Growth Ratio

5. Profit Margin on Sales

2) Customer Perspective

Customer perspective is a measurement of performance based on indicators of "Customer care measurement" and "Customer Value Proposition", indicators that can be used as follows[2]:

1. Customer growth

2. Customer satisfaction

Measurement of customer satisfaction on product / service attributes, including: function, price, and product quality. Customer relationships, including: product distribution to customers, including the response of the company, delivery time, and how the customer feels after purchasing the product / service from the company concerned. Citra and reputation, illustrating the intangible factor for the company to attract customers to deal with company, or purchase the product.

3) Internal Business Perspective

In this perspective, performance measurement of indicators that can be used as follows[2]:

1. Innovation Process

2. Operation Process

3. After Sales Service

4) Learning and Growth Perspective 
In this perspective, performance measurement is based on indicators of learning activities to achieve organizational goals indicators that can be used as follows [2]:

1. HR Productivity

2. Employee Satisfaction

3. Employee retention

Data analysis technique used in this research is descriptive technique by looking at fact data organization and analyze organizational performance based on perspectives that exist in balanced scorecard. In this analysis described and described the condition of the organization in the form of tables and simple analysis[3].

Stages of analysis performed include:

a) The scale used in this study is 5 scale, where 1 (one) is the lowest value and 5 is the highest rating.

b) Rating Stage: Measurement of ratings in each perspective is calculated as follows[4]:

$$
\text { Rating rating }=\frac{\text { Total Score rating }}{\text { Number of respondents }}
$$

c) Weighting Stages

The weighting assessment in each perspective is calculated by the following formula[4]:

$$
\text { Weight value }=\frac{\text { Number of interest scores }}{\text { Total score of interest }}
$$

After the above calculation activities the next step is to calculate the total score with the formula:

Total score $=$ Rating rating $\mathrm{x}$ Weight value

d) Design Balanced Scorecard Distributor Electrical

\section{SIMULATIONS AND RESULTS}

Table 1. BSC performance on Company of Distributor Electrical

\begin{tabular}{|l|c|c|c|}
\hline \multicolumn{1}{|c|}{ Perspective } & Score & Target & $\begin{array}{c}\text { Achievemen } \\
\mathbf{t}\end{array}$ \\
\hline financial & 5.00 & 5.00 & $100 \%$ \\
\hline customer & 3.09 & 5.00 & $61.8 \%$ \\
\hline internal business process & 3.04 & 5.00 & $60.8 \%$ \\
\hline learning and growth & 2.77 & 5.00 & $55.4 \%$ \\
\hline Key Performance Values & $\mathbf{1 3 . 9}$ & $\mathbf{2 0}$ & $\mathbf{6 9 . 5 \%}$ \\
\hline
\end{tabular}


In table 1 it can be explained that the Balanced Scorecard analysis in the company of distributor electrical found that the financial perspective score of 5 means $100 \%$ achievement, the Perspective of 3.08 means reach $61.8 \%$, the Internal Business Process Perspective of 3.04 means achieved $60.8 \%$, and the Learning and Growth Perspective 2.7 means reached 55.4\%.

The explanations of each of the perspectives in table 1 are as follows :

1. Financial Perspective

The performance of the financial perspective on Company of Distributor Electrical is actually very good, because the company has been able to increase the sales volume in each period, the increase of sales is due to the improvement of sales performance along with the increase of sales promotion and the increasing of marketing area. The increase in sales is also shown in the calculation of Return On Investment, Sales Growth Ratio of companies that have increased. But there is still a decrease in the company's Return On Equrty measurement. The decline in these indicators is due to the Company's inefficiency. it means that the ownership of the owner of the company is too large so that the capital position of the company owner is still not optimal. This can hamper the company's cashflow in sustain stage, because the company if it wants to be in the harvest stage should be more effective in managing assets to generate profits for the company.

2. Customer Perspective

If seen from the Customer Perspective on Company of Distributor Electrical is on the category good enough, on a scale of 3 . Where on the measurement of customer satisfaction by distributing questionnaires to customers can be seen the results with the average customer perceptions are expressed very well and good on product quality, service, and customer loyalty. But in the case of the selling price, the speed and accuracy of handling the shipping bidding request need to be minimized. This is because raw material prices always go up, and for delivery accuracy occurs because of Overload factory. To increase the value of customer perespektif on a scale of 4-5 then the company should be as much as possible to improve its management system with the speed and accuracy of providing the best service to its customers, and provide prices in accordance with competitors, so that customers will feel satisfied with every service provided by the company and ultimately can increase customer loyalty to the company.

3. Internal Business Process Perspective

In the Internal Business Process Perspective on Company of Distributor Electrical can be concluded is good enough, where the measurement results are in fairly good category or on a scale of 3 , because the defective products produced by the company, the amount can still be tolerated because it is not completely production errors. but the company always try to pay attention to productivity and accuracy of quality control performance. The complain concerning delivery service must be considered for customer satisfaction, to be loyal to the Company, so the value on this perspective can be increased on a scale of 4 or 5 .

4. Learning And Growth Perspective

In the perspective of growth and learning on Company of Distributor Electrical can be concluded that, the level of employee satisfaction and employee productivity as measured through the spread of questionnaires are in the category of less or are on a scale of 2-3. It is also shown from the phenomenon number of employees who qualify to get the main job is relatively less. To increase the value of scale in perspective of growth and learning on a 4-5 scale then the company needs to pay attention to employee productivity to improve the expertise that includes innovation, creativity and employee 
performance effectively and efficiently through a series of training activities and technical assistant from experts in the field either from parties internal company as well as from external parties company.

The results showed that to increase the sales volume so as to obtain optimal profit on an ongoing basis the company of distributor electrical needs to do the following steps:

1. In order for customer satisfaction and customer relationship to continue to increase, the company should pay attention to the causal relationships that exist in the balanced scorecard. The company of distributor electrical shall endeavor to improve the skills of each of its employees to be able to work actively, creatively, innovatively, effectively and efficiently so as to produce a quality product according to the customer's wishes at a more competitive price, and always on time in delivery, with which customers will be more satisfied with services provided by the company, can increase customer loyalty and the number of new customers[5]. The innovation is "changing the yield of resources," and innovation is aimed at enhancing the value and satisfaction of consumers with the use of their resources so as to create increased effectiveness rather than increased efficiency in resource use[6].

2. The company of distributor electrical must increase the amount of stock of goods (ready stock) to minimize the delay in the delivery process. Because inventory is the best solution to create cost-side advantages so as to create competitive pricing[7].

3. The company of distributor electrical are also encouraged to improve performance in the process of offering product prices. It is expected that the Company is more competitive in offering price so that it can be reached by its customers. In addition, the Leader must also always evaluate each employee's job in order to improve the accuracy and suitability of the procedures of its employees in working to improve the customer[8], [9]. The Company also in addition to vision and mission, company or organization also have to determine core value statement (core value), which explain soul, attitude, behavior and character which is very important to be developed in a company or organization[1].

4. The company of distributor electrical should be able to improve the employee's ability index so as to increase employee loyalty and be able to create mutual interactions between customers and companies[10]-[12]

5. Strategy model that can be developed by company of distributor electrical with BSC model is as follows:

a. Formulation of vision, mission, and strategic goals of the company of distributor electrical [13].

b. Formulation the company of distributor electrical strategy[14].

c. Selection of the Strategic on the company of distributor electrical perspective and strategic determination[12].

d. Determining the benchmarks of BSC of the company of distributor electrical [15].

e. The design drawings of BSC of the company of distributor electrical

f. Analysis of causal relationships

g. The depiction on the company of distributor electrical strategy chart

h. Analysis of the design of the Balanced Scorecard model[16] 


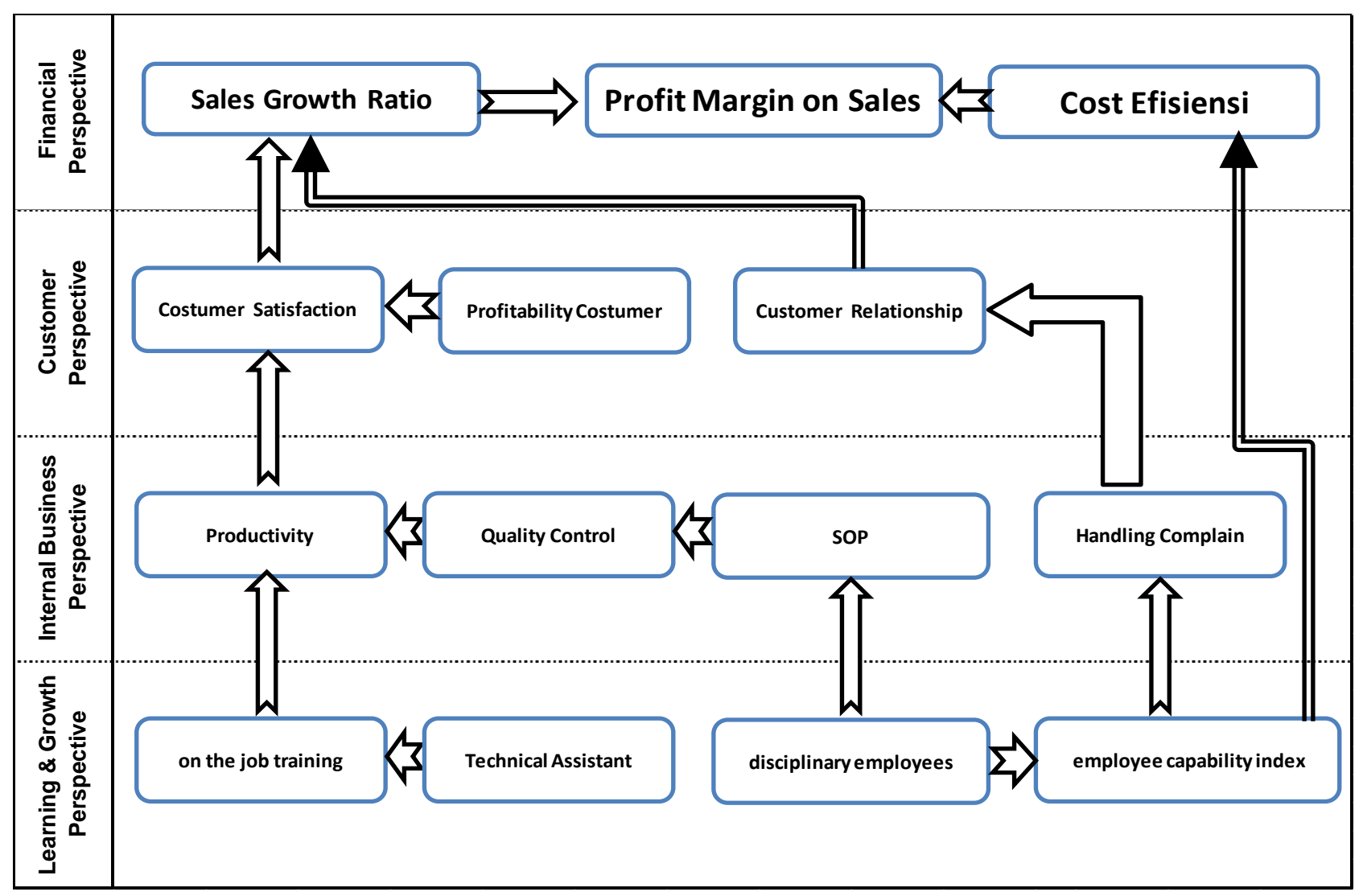

Picture 1. Map of Strategy of Electric Distributor Company

In Figure 1 Map of Strategy of Electric Distributor Company can be explained that the profit of sales obtained if the company is able to increase sales growth obtained through improving customer satisfaction by increasing productivity and customer relationship by improving the ability of handling complain and cost efficiency obtained through increased employee capability index and disciplinary employees.

\section{CONCLUSION}

The Balanced Scorecard analysis in the company of distributor electrical found that the financial perspective score 5, the Customer Perspective 3.08, the Internal Business Process Perspective of 3.04, and the Learning and Growth Perspective 2.7. Based on the results of the company score then determine the strategy to increase sales volume by increasing customer satisfaction through quality products with competitive prices, and increase the number of stock items. Optimizing the profit earned, so as to increase the company's ability to return capital to shareholders, by limiting the cost to the owner's personal needs.

Acknowledgment: The authors would like to The Electronic And Electrical Appliances Industry Association of Indonesia (APIEI) Surabaya area their appreciation for the support of with this Project.

\section{REFERENCES}

[1] A. R. S. Kaplan, M. Lagace, R. S. Kaplan, and D. P, "Strategy Execution and the Balanced Scorecard," Harv. Bus. Rev., pp. 1-3, 2008.

[2] R. S. Kaplan and D. P. Norton, "Transforming the balanced scorecard from performance 
measurement to strategic management: Part II," Accounting Horizons, vol. 15, no. 2. pp. 147-160, 2001.

[3] A. Sharma, "Implementing Balance Scorecard for Performance Measurement," ICFAI J. Bus. Strateg., vol. 6, no. 1, pp. 7-16, 2009.

[4] Freddy Rangkuti, Teknik Membedah Kasus Bisnis Analisis SWOT: Cara Perhitungan Bobot, Rating dan OCAI. 2014.

[5] D. D. Wilson, A., Zeithaml, V. A., Bitner, M. J., \& Gremler, Services marketing: Integrating customer focus across the firm. McGraw Hill, 2012.

[6] P. F. Drucker: and D. V. to Customers, "Peter F. Drucker: delivering value to customers," Meas. Bus. Excell., vol. 6, no. 4, p. mbe.2002.26706dae.007, 2002.

[7] D. R. Hansen and M. M. Mowen, Cost Managment Accounting \& Control. 2006.

[8] R. S. Kaplan and D. P. Norton, "The office of strategy management," Harvard Business Review, vol. 83, no. 10. 2005.

[9] P. L. Narayanamma, "A Study On Impact Of Balanced Scorecard Implementation On Job Satisfaction Of Employees In Selected Public And Private Sector," Shanlax Int. J. Arts, Sci. Humanit., vol. 4, no. 3, pp. 44-52, 2017.

[10] G. Dessler, “Human Resource Management," Int. J. Bus. Adm., vol. 2, no. 3, pp. 45-60, 2008.

[11] P. F. Buller and G. M. McEvoy, "Strategy, human resource management and performance: Sharpening line of sight," Human Resource Management Review, vol. 22, no. 1. pp. 43-56, 2012.

[12] S. ANSARI, "The Execution Premium : Linking Strategy to Operations for Competitive Advantage," Account. Rev., vol. 85, no. 4, pp. 1475-1477, 2010.

[13] J. Labarta, E. Ayguadé, and M. Valero, "BSC vision towards exascale," Int. J. High Perform. Comput. Appl., vol. 23, no. 4, pp. 340-343, 2009.

[14] D. P. N. Robert S. Kaplan, The Strategy-focused Organization: How Balanced Scorecard Companies Thrive in the New Business Environment. Boston: Harvard Business School Press, 2001.

[15] C. Schawel and F. Billing, "Balanced Scorecard (BSC)," in Top 100 Management Tools, 2009, pp. 34-36.

[16] J. K. Khomba, "Conceptualisation of the Balanced Scorecard (BSC) model," Int. J. Commer. Manag., vol. 25, no. 4, pp. 424-441, 2015. 